\title{
p75 neurotrophin receptor: A potential surface marker of tongue squamous cell carcinoma stem cells
}

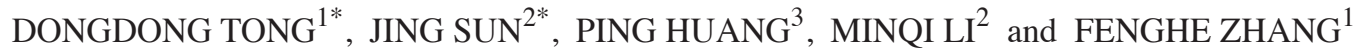 \\ Departments of ${ }^{1}$ Oral and Maxillofacial Surgery and ${ }^{2}$ Bone Metabolism, \\ School of Stomatology, Shandong Provincial Key Laboratory of Oral Tissue Regeneration, Shandong University; \\ ${ }^{3}$ Department of Gynecology, Qilu Hospital, Shandong University, Jinan, Shandong 250012, P.R. China
}

Received October 29, 2015; Accepted November 3, 2016

DOI: $10.3892 / \mathrm{mmr} .2017 .6291$

\begin{abstract}
The present study detected $\mathrm{p} 75$ neurotrophin receptor (p75 ${ }^{\mathrm{NTR}}$ ) expression in tongue squamous cell carcinoma (TSCC) cell lines, in order to define the biological properties of p75 ${ }^{\mathrm{NTR}+}$ cells and to confirm the use of $\mathrm{p} 75^{\mathrm{NTR}+}$ as a surface marker for TSCC stem cells. p75 ${ }^{\mathrm{NTR}+}$ cells were separated from Tca-8113 and CAL-27 TSCC cells by fluorescence-activated cell sorting. Colony formation, MTT and scratch assays, and a tumorigenicity analysis were performed to measure self-renewal and proliferation, multidirectional differentiation, and tumorigenicity of p75 ${ }^{\mathrm{NTR}+}$ cells. p75 ${ }^{\mathrm{NTR}+}$ cells comprised 3.1 and $1.9 \%$ of Tca-8113 and CAL-27 cells (mean of three experiments), respectively, and were more able to form colonies compared with non-sorted cells $(\mathrm{P}<0.01)$. In addition, the proportion of $\mathrm{p} 75^{\mathrm{NTR}+}$ cells generated from monoclonal $\mathrm{p} 75^{\mathrm{NTR}+}$ cells decreased to 14.5 (Tca-8113) and 5.8\% (CAL-27) of cells within 2 weeks, thus suggesting that $\mathrm{p} 75^{\mathrm{NTR}+}$ cells are able to generate p $75^{\mathrm{NTR}+}$ and p $75^{\mathrm{NTR}-}$ cells. Furthermore, p75 $5^{\mathrm{NTR}+}$ cells exhibited increased proliferation, as evidenced by MTT assay $(\mathrm{P}<0.01)$ and had greater metastatic ability according to the scratch assay $(\mathrm{P}<0.01)$, compared with non-sorted cells. p75 ${ }^{\mathrm{NTR}+}$ cells also exhibited a greater tumorigenic capacity compared with non-sorted cells. In conclusion, $\mathrm{p} 75^{\mathrm{NTR}+}$ cells isolated from TSCC cell lines possess the characteristics of cancer stem cells; therefore, $\mathrm{p} 75^{\mathrm{NTR}}$ may be considered a useful surface marker for the identification of TSCC stem cells.
\end{abstract}

Correspondence to: Professor Fenghe Zhang, Department of Oral and Maxillofacial Surgery, School of Stomatology, Shandong Provincial Key Laboratory of Oral Tissue Regeneration, Shandong University, 44-1 Wenhua West Road, Jinan, Shandong 250012, P.R. China

E-mail: zfengh@sdu.edu.cn

*Contributed equally

Key words: tongue squamous cell carcinoma, Tca-8113, CAL-27, cancer stem cells, p75 ${ }^{\mathrm{NTR}}$, flow cytometry

\section{Introduction}

Oral squamous cell carcinoma (OSCC) accounts for $>90 \%$ of head and neck carcinomas; and, of these 90\%, OSCCs of the tongue (TSCC) are reported to occur with rates of up to $40-50 \%$ (1). In order to enhance patient survival following TSCC, surgical techniques and diagnostic accuracy have improved; however, treatment failure persists due to local recurrence, and regional lymph node and distant metastases are common. It is well known that treatment failure may be associated with cancer stem cells (CSCs) or 'tumor-initiating cells' (2-4), which exhibit long-term self-renewal and a high migratory capacity, as well as the ability to generate phenotypically diverse tumor cells (5). This behavior is explained by the 'cancer stem cell' theory (6), which is a basis for oncology research $(4,7,8)$. Previous studies in OSCC-derived cell lines have indicated that cell subpopulations with phenotypic and behavioral characteristics of normal epithelial stem cells may initiate tumorigenesis in vivo $(9,10)$. CSCs rarely divide; however, they can produce fast-proliferating daughter cells. The majority of CSCs in various types of cancer have been isolated from tumor cells based on marker expression that characterizes stem cells in normal tissues (11). However, few studies have focused on the expression and function of a reliable marker to identify TSCC stem cells; therefore, at present, there is little understanding regarding their behavior and fate.

It has previously been reported that the p75 neurotrophin receptor ( $\mathrm{p} 75^{\mathrm{NTR}}$ ) may be involved in the invasion and poor prognosis of OSCC (12). As a member of the tumor necrosis factor superfamily, $\mathrm{p} 75^{\mathrm{NTR}}$ is a $75-\mathrm{kDa}$ cell-surface receptor glycoprotein $(13,14)$, which is involved in diverse cellular responses, including cell proliferation and survival, and apoptosis in neural and non-neural tissues $(15,16)$ via unique pathways $(17,18)$ or activation of the intrinsic caspase pathway (19). Furthermore, the expression and diverse function of $\mathrm{p} 75^{\mathrm{NTR}}$ has previously been reported in numerous types of cancer (20-22). Okumura et al (23) reported that $\mathrm{p} 75^{\mathrm{NTR}+}$ esophageal epithelial cells were actually stem cells, since they were able to proliferate, self-renew and undergo multidirectional differentiation. In addition, $\mathrm{p} 75^{\mathrm{NTR}}$ has been used to screen and identify mouse testis peritubular smooth muscle precursors (24), rat adipose multipotent stem cells (25) and human corneal epithelial progenitor cells (26). 
The present study detected $\mathrm{p} 75^{\mathrm{NTR}}$ expression in Tca- 8113 and CAL-27 TSCC cell lines, and noted that $\mathrm{p} 75^{\mathrm{NTR}+}$ TSCCs exhibited CSC properties, particularly with regards to self-renewal and proliferation, multidirectional differentiation, and strong in vivo tumorigenic capacity.

\section{Materials and methods}

Cell source and culture conditions. Tca-8113 and CAL-27 TSCC cell lines were kindly provided by the Shanghai Key Laboratory of Stomatology (Department of Oral and Maxillofacial-Head Neck Oncology, Ninth People's Hospital, Shanghai Jiao Tong University School of Medicine, Shanghai, China). The cell lines were originally purchased from the Shanghai Cell Biology Institute of the Chinese Academy of Sciences (Shanghai, China).

Tca-8113 cells were cultured in RPMI-1640 medium (Invitrogen; Thermo Fisher Scientific, Inc., Waltham, MA, USA) supplemented with $10 \%(\mathrm{v} / \mathrm{v})$ fetal bovine serum (FBS; HyClone; GE Healthcare Life Sciences, Chalfont, UK), $100 \mathrm{IU} / \mathrm{ml}$ penicillin and $100 \mathrm{mg} / \mathrm{ml}$ streptomycin (Invitrogen; Thermo Fisher Scientific, Inc.). CAL-27 cells were cultured in Dulbecco's modified Eagle's medium (DMEM; HyClone; GE Healthcare Life Sciences) supplemented with 10\% (v/v) FBS, $100 \mathrm{IU} / \mathrm{ml}$ penicillin and $100 \mathrm{mg} / \mathrm{ml}$ streptomycin. All cell cultures were maintained in a humidified incubator containing $5 \% \mathrm{CO}_{2} / 95 \%$ air at $37^{\circ} \mathrm{C}$.

Flow cytometry and fluorescence-activated cell sorting (FACS). Tumor cells were harvested (final concentration, $1 \times 10^{6}$ cells $/ \mathrm{ml}$ ) with Buffer 1 (PBS containing $0.5 \%$ bovine serum albumin (Sigma-Aldrich; Merck Millipore, Darmstadt, Germany) and $2 \mathrm{mM}$ EDTA). Cells were then incubated with the primary antibody for $2 \mathrm{~h}$ at $4^{\circ} \mathrm{C}$, washed twice in Buffer 1 , and were resuspended in $500 \mu \mathrm{l}$ Buffer 1, to which phycoerythrin (PE)-conjugated goat anti-mouse immunoglobulin $\mathrm{G}$ at a dilution of 1:100 (cat. no. 555749; BD Pharmingen, San Diego, CA, USA) was added. Cells were incubated in the dark for $15 \mathrm{~min}$ at $4^{\circ} \mathrm{C}$. After staining, the samples were analyzed using a FACSCalibur flow cytometer with CellQuest software (version 5.1; BD Biosciences, San Jose, CA, USA). The primary antibody used was mouse anti-human p75 ${ }^{\mathrm{NTR}}$ at a dilution of 1:100 (cat. no. 557196; BD Pharmingen). FACS of p75 ${ }^{\mathrm{NTR}+}$ cells was performed using a Cytomation $\mathrm{MoFlo}^{\circledR}$ cytometer (Dako; Agilent Technologies, Santa Clara, CA, USA). The top 25\% most brightly stained cells were isolated as p $75^{\mathrm{NTR}+}$ cells; cells incubated with PE-conjugated antibodies only were used as controls.

Colony formation assay. $75^{\mathrm{NTR}+}$ single cell suspensions were prepared, diluted, and plated into a 96-well plate at various densities $\left(1 \times 10^{6} / \mathrm{ml} ; 1 \times 10^{5} / \mathrm{ml} ; 1 \times 10^{4} / \mathrm{ml} ; 1 \times 10^{3} / \mathrm{ml}\right.$; $\left.1 \times 10^{2} / \mathrm{ml}\right)(27)$. Cells were allowed 2 weeks to form colonies under standard conditions, and the rate at which this occurred was recorded. To assess $\mathrm{p} 75^{\mathrm{NTR}+}$ differentiation, colonies formed by one cell type were collected and incubated for another 2 weeks for $\mathrm{p} 75^{\mathrm{NTR}+}$ flow cytometric analysis.

MTT cell viability assay. Briefly, sorted $\mathrm{p} 75^{\mathrm{NTR}+}$ cells, and non-sorted Tca-8113 and CAL-27 cells $\left(4 \times 10^{3}\right.$ cells/well) were seeded in 96-well plates. After 1, 2, 3, 4, 5, 6 or 7 days, $100 \mu 1$ MTT $(5 \mathrm{mg} / \mathrm{ml})$ was added, followed by incubation for a further $4 \mathrm{~h}$ at $37^{\circ} \mathrm{C}$. The reaction was terminated by replacing MTT-containing medium with $100 \mu 1$ acidic isopropanol (10\% SDS, 5\% isopropanol, $0.01 \mathrm{~mol} / \mathrm{l} \mathrm{HCl}$ ); the resulting formazan crystals were dissolved by gentle agitation for $\sim 10 \mathrm{~min}$ at room temperature. For colorimetric analysis, absorbance $(490 \mathrm{~nm})$ was measured on a microplate reader (Bio-Rad Laboratories, Inc., Hercules, CA, USA). The optical density (OD) values were analyzed using Quantity One analysis software (version 29.0; Bio-Rad Laboratories, Inc.). Each assay was repeated at least three times. Relative cell viability was compared to untreated (blanks) cells.

Scratch assay. Live tumor cells (Tca-8113 and CAL-27) were harvested from standard cultures and grown to confluence on 6-well Permanox ${ }^{\mathrm{TM}}$ plates. Consistently shaped wounds were made using a sterile $200 \mu \mathrm{l}$ pipette tip across each well, creating a cell-free area, according to previously described methods (28). Cultures were gently washed with PBS to remove loose cells and adherent cells were maintained in culture medium supplemented with $1 \%$ FBS. Non sorted control cells were also scratched, washed, and maintained in culture medium supplemented with $1 \%$ FBS after scratching. Immediately after scratching and at $12 \mathrm{~h}, 3,4,5$ and $8 \mathrm{~d}$, images of the scraped areas were captured under phase contrast microscopy. The wounded areas and scratch widths were measured at six different points per image, and the same scratched area was used for every assessment.

Xenograft tumorigenicity assay. Throughout experiments, animals were maintained under the Guidelines for Animal Experimentation of the School and Hospital of Stomatology, Shandong University (Jinan, China). Experiments were conducted according to the National Institute of Health Guidelines for Research Involving Recombinant or Synthetic Nucleic Acid Molecules (November, 2013) the (regarding the care and use of animals for experimental procedures. In addition, the present study was independently reviewed and approved by the Animal Experimentation Committee of Shandong University, and was approved by the Medical Ethics Committee of the School of Medicine, Shandong University.

Briefly, 5-6 week-old male BALB/c nude mice $(\sim 18 \pm 1.2 \mathrm{~g}$; $\mathrm{n}=106)$ were obtained from Beijing Vital River Laboratory Animal Technology Co., Ltd. (Beijing, China), and were maintained in plastic cages ( $\mathrm{n}=3-5 /$ cage) under standard laboratory conditions with a $12 \mathrm{~h}$ dark, $12 \mathrm{~h}$ light cycle and a constant temperature of $23^{\circ} \mathrm{C}$ and humidity of $48 \%$. All mice were fed a standard rodent diet ad libitum. After 1 week of acclimation, mice were randomly divided into four groups (named as follows: $75 \mathrm{NTR}^{+}$, Tca- 8113 cells, non-sorted Tca-8113 cells, p75NTR ${ }^{+}$CAL-27 cells and non-sorted CAL-27 cells injection; $n=24$ /group) and each group was subdivided into four subgroups ( $\mathrm{n}=6 /$ subgroup). Four cell suspensions of $\mathrm{p} 75^{\mathrm{NTR}+}$ and non-sorted cells were prepared $\left(1.0 \times 10^{3} / \mathrm{ml}, 1.0 \times 10^{4} / \mathrm{ml}\right.$, $1.0 \times 10^{5} / \mathrm{ml}$ and $1.0 \times 10^{6} / \mathrm{ml}$ ) in $200 \mu 1$ serum-free DMEM. These suspensions were injected subcutaneously into BALB/c nude mice, following anesthetization with $10 \%$ chloral hydrate (400 mg/100 g body weight) at room temperature. Tca-8113 

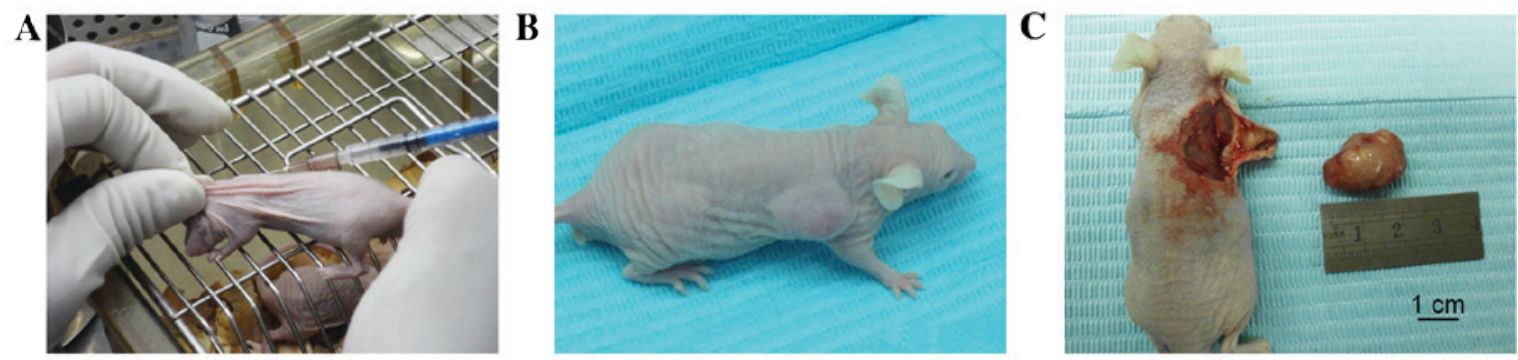

Figure 1. Nude mice xenograft model formed using p $75^{\mathrm{NTR}+}$ Tca- 8113 cells. (A) Inoculation of tumor cells into the backs of the mice. (B) Tumor formation after 4 weeks, and (C) removal of the tumor after 6 weeks. p75 ${ }^{\mathrm{NTR}}$, p75 neurotrophin receptor.
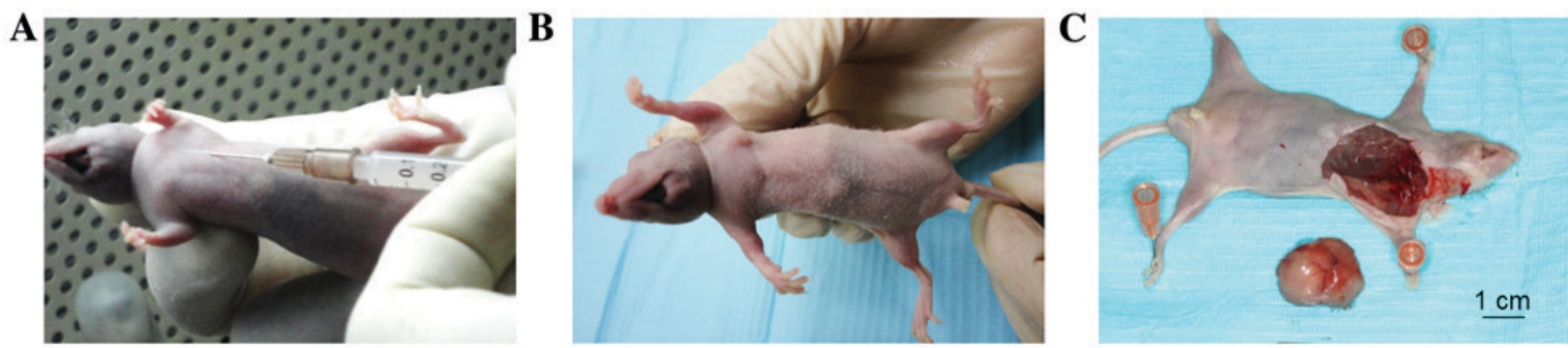

Figure 2. Nude mice xenograft model formed using p $75^{\mathrm{NTR}+}$ CAL-27 cells. (A) Inoculation of tumor cells into the axilla. (B) Tumor formation after 2 weeks, and $(\mathrm{C})$ removal of the tumor after 6 weeks. p75 ${ }^{\mathrm{NTR}}$, p75 neurotrophin receptor.

cells were injected into the backs of the mice (Fig. 1), whereas CAL-27 cells were injected into the axilla of the mice (Fig. 2). Sterile PBS was injected into the contralateral side as a control.

At the end of the experiment, the mice were anesthetized as aforementioned (10\% chloral hydrate, $400 \mathrm{mg} / 100 \mathrm{~g}$ ) and subjected to transcardial perfusion with a fixative of $4 \%$ paraformaldehyde in $0.1 \mathrm{M}$ phosphate buffer (pH 7.4) 6 weeks following tumor cell inoculation. Subsequently, tumors were removed and immersed in the same fixative for an additional $24 \mathrm{~h}$ at $4^{\circ} \mathrm{C}$. Samples were dehydrated with graded ethanol and were embedded in paraffin according to standard procedures. Subsequently, $5-\mu \mathrm{m}$ serial sections were prepared for histological hematoxylin and eosin (H\&E) staining (LEICA SM 2010R; Leica Microsystems GmbH, Wetzlar, Germany).

Histological examination and image analysis. $\mathrm{H} \& \mathrm{E}$ staining was performed to investigate the morphology. The prepared sections were immersed in Erthlich's haematoxylin for $15 \mathrm{~min}$. Then the sections were washed with distilled water and differentiated in $1 \% \mathrm{HCl}$ in $70 \%$ alcohol for $1 \mathrm{~min}$ and washed again for $2 \mathrm{~min}$. After that, the sections were stained with $1 \%$ eosin for $10 \mathrm{~min}$ and washed with distilled water. Finally, all sections were dehydrated and mounted. The stained sections were observed and then digital images were taken with a light microscope (Olympus BX-53; Olympus Corporation, Tokyo, Japan).

Statistical analysis. For comparing distant metastases between p $75^{\mathrm{NTR}+}$ and negative groups, a $\chi^{2}$ test was performed. Fisher's exact test was used to compare tumorigenicity between $\mathrm{p} 75^{\mathrm{NTR}+}$ and negative groups. Other experimental data are presented as the mean \pm standard deviation and were analyzed using Student's t-test. $\mathrm{P}<0.05$ was considered to indicate a statistically significant difference. Statistical analyses were conducted using SPSS 19.0 software (SPSS Inc., Chicago, IL, USA).

\section{Results}

Flow cytometry. $\mathrm{p} 75^{\mathrm{NTR}+}$ cells were detected in both TSCC cell lines (Fig. 3). p75 ${ }^{\mathrm{NTR}+}$ cells accounted for 3.1 and $1.9 \%$ of Tca-8113 and CAL-27 cells, respectively (an average of three experiments). After cell sorting, $\mathrm{p} 75^{\mathrm{NTR}+}$ cells accounted for 98.1 (Tca-8113) and 97.4\% (CAL-27) of all sorted cells (Fig. 4).

Colony formation assay. The colony-forming ability of p75 $5^{\mathrm{NTR}+}$, and non-sorted Tca-8113 and CAL-27 TSCC cells (Fig. 5) was assessed. The number of colonies formed by p $75^{\mathrm{NTR}+}$ cells from each cell line was greater compared with the number formed by non-sorted TSCC cells (Table I). Following 2 weeks of culture, monoclonal p $75^{\mathrm{NTR}+}$ cells were collected and cultured for a further 2 weeks, after which they were analyzed by flow cytometry. Data indicated that the colonies contained both $\mathrm{p} 75^{\mathrm{NTR}+}$ and $\mathrm{p} 75^{\mathrm{NTR}-}$ cells. The proportion of p $75^{\mathrm{NTR}+}$ cells in the Tca-8113 and CAL-27 cell populations was 14.5 and $5.8 \%$, respectively (Fig. 6). These results indicated that $\mathrm{p} 75^{\mathrm{NTR}+}$ cells exhibit self-renewing and multidirectional differentiation properties.

MTT cell viability assay. To determine the proliferative ability of $\mathrm{p} 75^{\mathrm{NTR}+}$ and non-sorted cells in vitro, an MTT assay was conducted. The results revealed no differences in proliferative ability, according to OD values, on the first day (Fig. 7). After 3 days of culture, OD values for the p75 $5^{\mathrm{NTR}+}$ cells were greater compared with the non-sorted cells $(\mathrm{P}<0.05)$, indicating a stronger proliferative ability of $\mathrm{p} 75^{\mathrm{NTR}+}$ cells in vitro. Furthermore, proliferation was greater on days 5 and 7 $(\mathrm{P}<0.01 ;$ Fig. 7). 

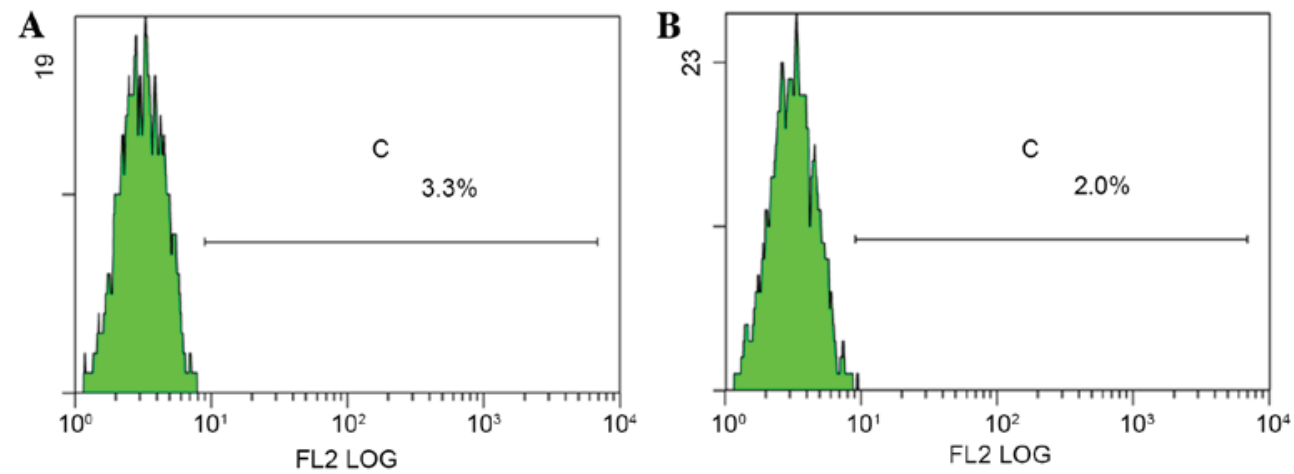

Figure 3. Flow cytometry. p75 ${ }^{\mathrm{NTR}+}$ cells (average of three experiments) in (A) Tca-8113 and (B) CAL-27 tongue squamous cell carcinoma cell lines. The average of three experiments indicated that the proportion of p75 ${ }^{\mathrm{NTR}+}$ cells was 3.1 and $1.9 \%$ in Tca-8113 and CAL-27 cells, respectively. p75 ${ }^{\mathrm{NTR}}$, p75 neurotrophin receptor.

$\mathbf{A}$

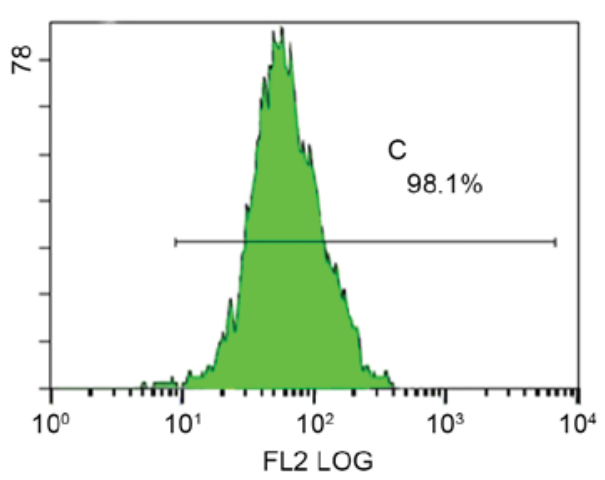

B

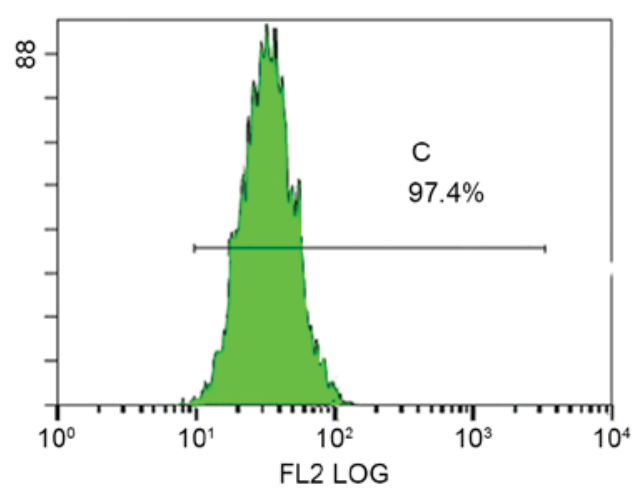

Figure 4. p75 ${ }^{\mathrm{NTR}+}$ sorted cells from (A) Tca-8113 and (B) CAL-27 tongue squamous cell carcinoma cell lines. p75 ${ }^{\mathrm{NTR}+}$ cells were sorted and accounted for 98.1 (Tca-8113) and 97.4\% (CAL-27) of sorted cells. p75 ${ }^{\mathrm{NTR}}$, p75 neurotrophin receptor.

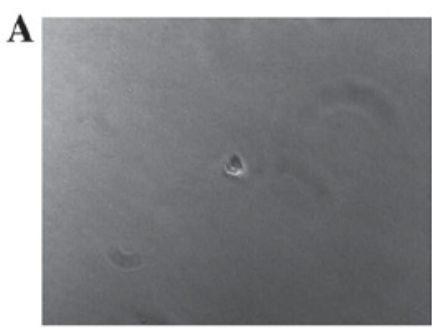

$\mathbf{B}$

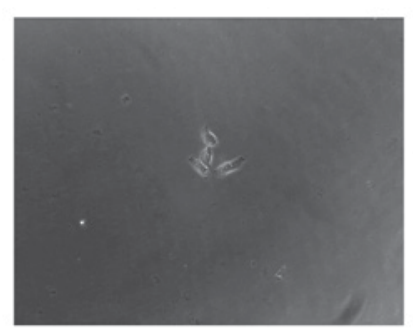

D

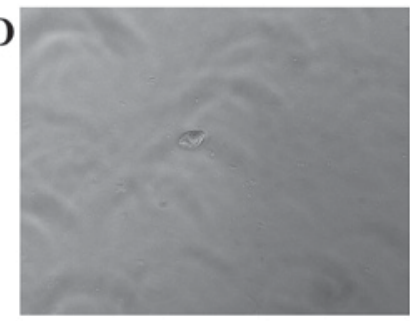

$\mathbf{E}$

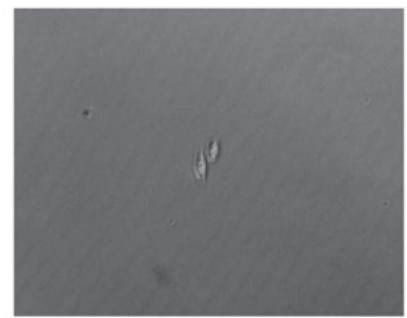

C

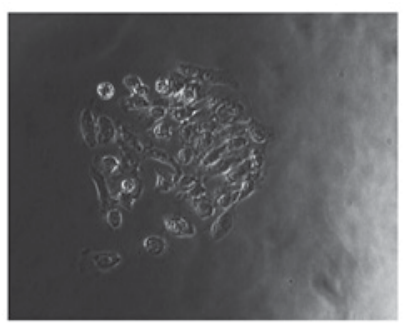

F

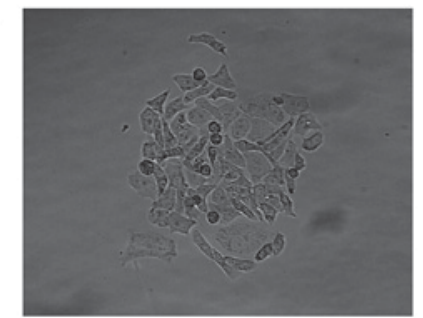

Figure 5. Colony formation assay for (A-C) p75 ${ }^{\mathrm{NTR}+}$ Tca-8113 and (D-F) p75 ${ }^{\mathrm{NTR}+}$ CAL-27 cells. Cell colonies formed by Tca-8113 TSCC single cells in culture after (A) $12 \mathrm{~h}$, (B) $48 \mathrm{~h}$ and (C) 7 days of culture. Colonies formed by CAL-27 TSCC single cells after (D) $12 \mathrm{~h}$, (E) $48 \mathrm{~h}$ and (F) 7 days of culture. Single TSCC cells proliferated in normal culture and formed colonies. A total of 2-7 days after plating, colony formation was observed. TSCC, tongue squamous cell carcinoma. A-F, x400 magnification.

Scratch assay. Cells in each group were observed 8 days after the scratch assay and the data indicated that $\mathrm{p} 75^{\mathrm{NTR}+}$ cells exhibited better wound healing compared with the controls (Figs. 8 and 9). By day 8, the wounded area in the Tca-8113 p $75^{\mathrm{NTR}+}$ cell group was covered, whereas non-sorted cells still retained a denuded area (Fig. 8). In the CAL-27 p75 ${ }^{\mathrm{NTR}+}$ cell group, cells covered the wounded area by day 5 (Fig. 9). These results suggested that $\mathrm{p} 75^{\mathrm{NTR}+}$ cells exhibit better migratory and invasive characteristics compared with non-sorted cells (Tca-8113, P<0.05; CAL-27, P<0.05; Fig. 10). 
Table I. Colony formation between $\mathrm{p} 75^{\mathrm{NTR}+}$ and non-sorted cells.

\begin{tabular}{|c|c|c|c|}
\hline Cell line & $\mathrm{p} 75^{\mathrm{NTR}+}$ cell colony formation $(\%)$ & Non-sorted cell colony formation (\%) & P-value \\
\hline Tca-8113 & $32.92 \pm 1.91$ & $7.09 \pm 1.20$ & $\mathrm{P}=0.0001$ \\
\hline CAL-27 & $34.96 \pm 2.03$ & $5.54 \pm 2.16$ & $\mathrm{P}=0.0001$ \\
\hline
\end{tabular}

p75 ${ }^{\mathrm{NTR}}, \mathrm{p} 75$ neurotrophin receptor.
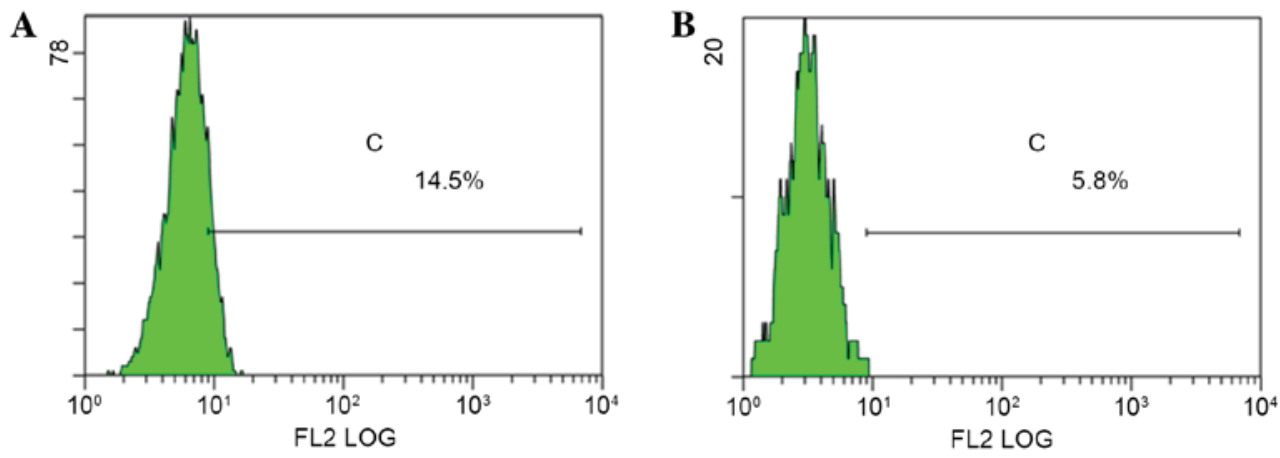

Figure 6. p75 ${ }^{\mathrm{NTR}+}$ cell colonies formed by sorted cells from (A) Tca-8113 and (B) CAL-27 tongue squamous cell carcinoma cell lines. Flow cytometry confirmed that colonies contained $\mathrm{p} 75^{\mathrm{NTR}+}$ and $\mathrm{p} 75^{\mathrm{NTR}-}$ cells. p $75^{\mathrm{NTR}+}$ cells accounted for 14.5 and $5.8 \%$ of Tca-8113 and CAL-27 cells, respectively. p75 ${ }^{\mathrm{NTR}+}$ cells exhibited self-renewing and differentiation abilities. $\mathrm{p} 75^{\mathrm{NTR}}$, p75 neurotrophin receptor.

A

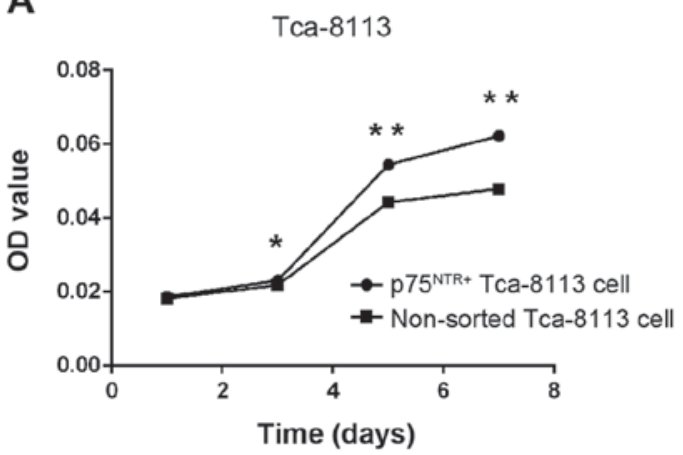

B

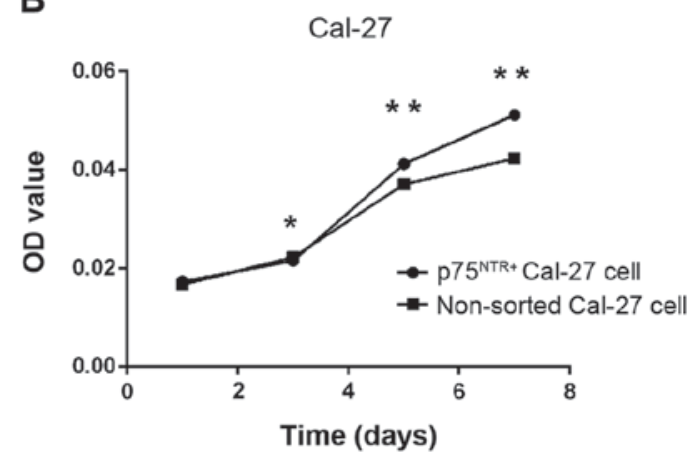

Figure 7. Growth curves of sorted p75 ${ }^{\mathrm{NTR}+}$ cells and non-sorted cells from the (A) Tca-8113 and (B) CAL-27 tongue squamous cell carcinoma cell lines. Cell growth curves were determined using MTT assay. No differences in proliferative ability (OD values) were detected on day 1 . After 3 days of culture, OD values for $\mathrm{p} 75^{\mathrm{NTR}+}$ cells were greater compared with non-sorted cells ( $\left.{ }^{*} \mathrm{P}<0.05\right)$, indicating stronger proliferative ability of p75 ${ }^{\mathrm{NTR}+}$ cells in vitro. Proliferation was increased on days 5 and $7\left(^{* *} \mathrm{P}<0.01\right)$. $\mathrm{P}<0.05$ vs. non-sorted cells. p75 ${ }^{\mathrm{NTR}}$, p75 neurotrophin receptor; OD, optical density.

Xenograft tumorigenicity assay. Various numbers of sorted $\mathrm{p} 75^{\mathrm{NTR}+}$ and non-sorted TSCC cells were injected into nude mice, as aforementioned. The results indicated that at least $5 \times 10^{3}$ p $75^{\mathrm{NTR}+}$ cells or $5 \times 10^{4}$ non-sorted cells were required to generate tumors. Tumorigenicity of the $\mathrm{p} 75^{\mathrm{NTR}+}$ and non-sorted cell groups are presented in Table II. Tumorigenicity of $\mathrm{p} 75^{\mathrm{NTR}+}$ cells was significantly higher compared with non-sorted cells according to Fisher's exact test.

H\&E staining was used to identify morphological differences between the treatment groups. Stained sections were observed and digital images were captured under a light microscope (Olympus BX-53; Olympus Corporation). Both tumor types appeared to be squamous cell carcinomas with no intercellular bridges and undetectable mitosis. Tumors originating from Tca-8113 cells had larger necrotic areas compared with those generated from CAL-27 cells. The tumor cell lines generated abundant cancer cell nests, thus resembling normal human, moderately differentiated TSCC (Fig. 11).

\section{Discussion}

p75 ${ }^{\text {NTR }}$ expression was present in Tca-8113 and CAL-27 TSCC cell lines, as indicated in the results of the present study; these data were similar to those of previous studies, which detected the presence of cancer stem cells (CSCs) $(29,30)$. p75 $5^{\mathrm{NTR}+}$ cells isolated from TSCC cell lines exhibited characteristics of CSCs, and were able to self-renew, proliferate and undergo multidirectional differentiation. Furthermore, p $75^{\mathrm{NTR}+}$ cells exhibited strong tumorigenic capacity in vivo. These results 


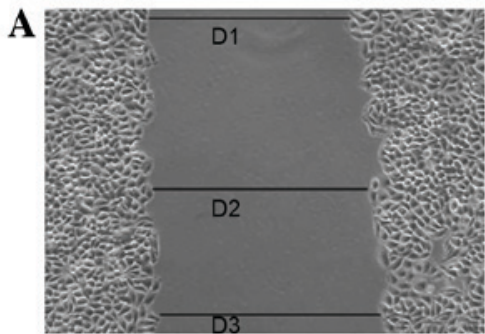

B
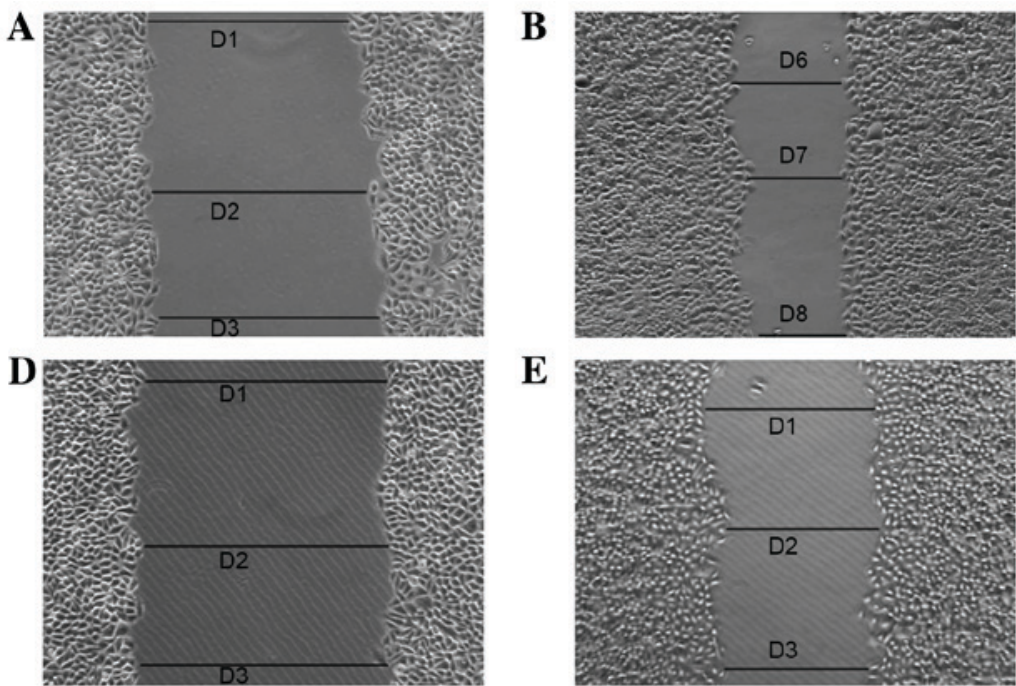

$\mathbf{E}$

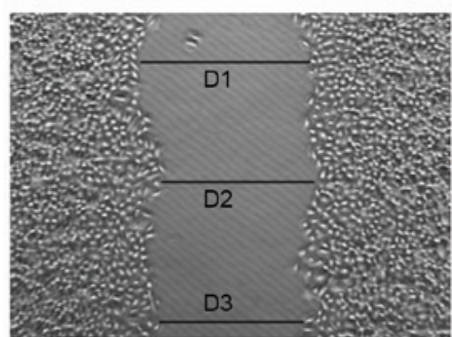

C

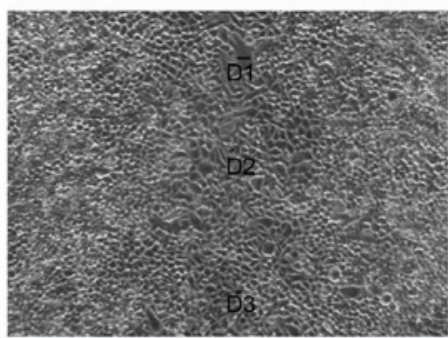

$\mathbf{F}$

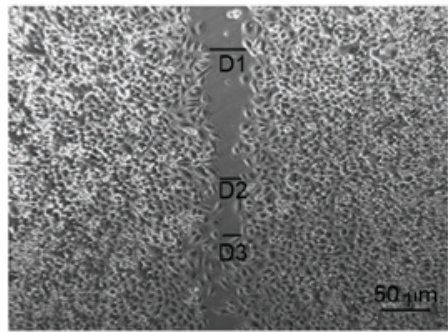

Figure 8. Scratch assay of Tca-8113 tongue squamous cell carcinoma cells. p75 ${ }^{\mathrm{NTR}+}$ cell group at (A) the time of scratching, (B) after 4 days and (C) after 8 days . Non-sorted cells at (D) the time of scratching, (E) after 4 days and (F) after 8 days. p75 ${ }^{\text {NTR }}$, p75 neurotrophin receptor. A-F, x40 magnification.
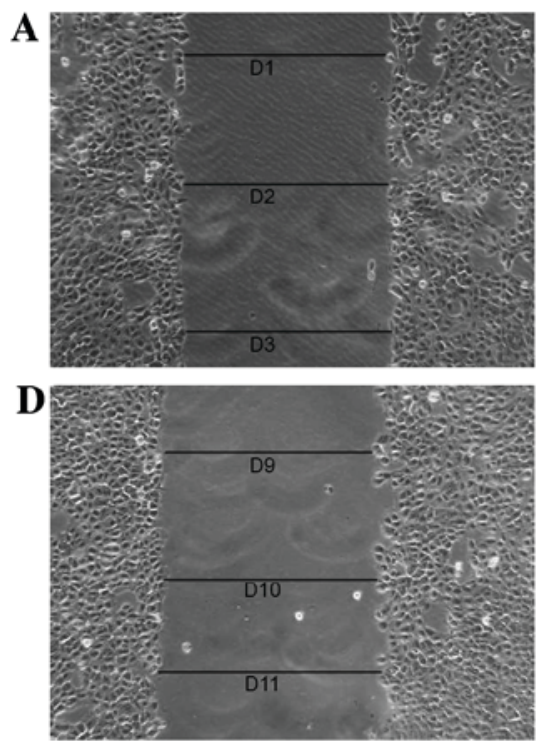

B

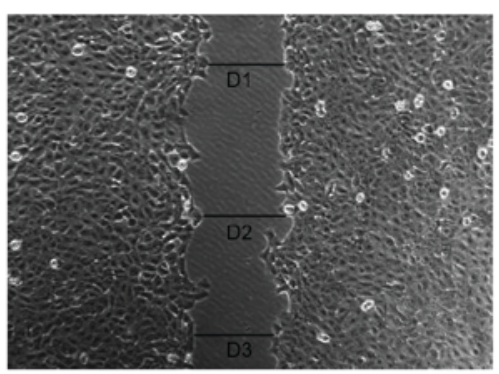

$\mathbf{E}$

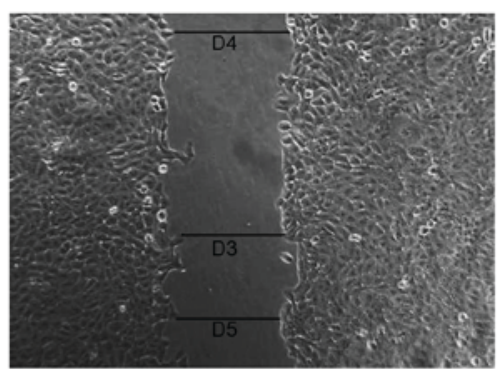

$\mathbf{C}$

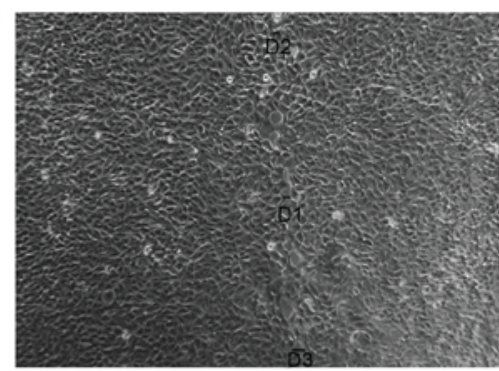

$\mathbf{F}$

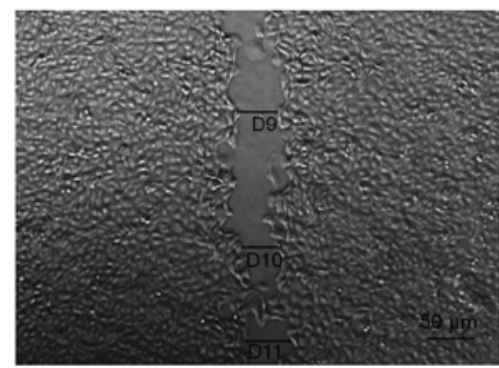

Figure 9. Scratch assay of CAL-27 tongue squamous cell carcinoma cells. p75 ${ }^{\mathrm{NTR}+}$ cell group at (A) the time of scratching, (B) after 3 days later and (C) after 5 days. Non-sorted cells at (D) the time of scratching, (E) after 3 days and (F) after 5 days. p75 $75^{\text {NTR }}$, p75 neurotrophin receptor. A-F, x40 magnification.
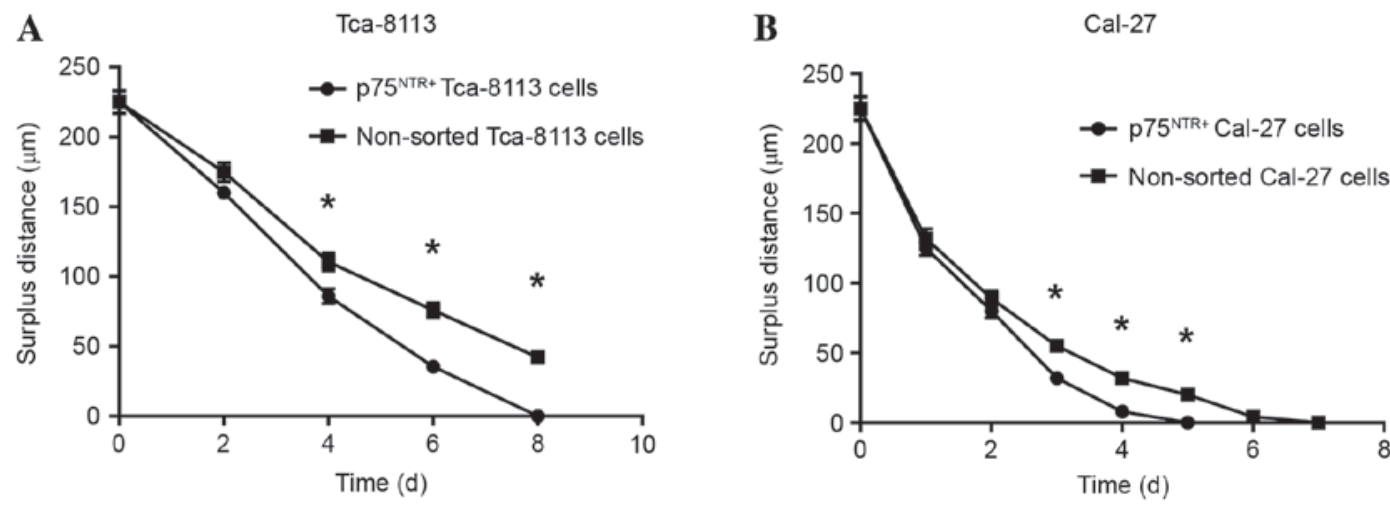

Figure 10. Surplus distance curve of sorted p75 ${ }^{\mathrm{NTR}+}$ and non-sorted (A) Tca-8113 and (B) CAL-27 tongue squamous cell carcinoma cells. After the scratch assay, cells from each group were observed for 8 days; $\mathrm{p}^{\mathrm{NTR}+}$ cells healed better than control cells. By day 8 , the wounded area of the Tca- 8113 p $75^{\mathrm{NTR}+}$ group was covered, whereas the non-sorted group retained a denuded area. By day 5 , the wounded area of the CAL- 27 p $75^{\mathrm{NTR}+}$ group was covered. p75 $5^{\mathrm{NTR}+}$ cells exhibit better migratory and invasive characteristics compared with non-sorted cells (Tca-8113, $\mathrm{P}<0.05$; CAL-27, $\mathrm{P}<0.05$ ). ${ }^{\text {P }}<0.05$ vs. non-sorted cells. p75 ${ }^{\mathrm{NTR}}$, p75 neurotrophin receptor. 
Table II. Tumorigenicity of $\mathrm{p} 75^{\mathrm{NTR}+}$ and non-sorted tongue squamous cell carcinoma cells in a nude mouse xenograft model.

Cell orders of magnitude/tumor numbers

\begin{tabular}{|c|c|c|c|c|c|}
\hline \multirow[b]{2}{*}{ Cell group } & & \multirow[b]{2}{*}{ P-value } \\
\hline & $1.0 \times 10^{3}$ & $1.0 \times 10^{4}$ & $1.0 \times 10^{5}$ & $1.0 \times 10^{6}$ & \\
\hline p75 $5^{\mathrm{NTR}+}$ Tca- 8113 cells & $1 / 6$ & $5 / 6$ & $6 / 6$ & $6 / 6$ & \\
\hline Non-sorted Tca-8113 cells & $0 / 6$ & $2 / 6$ & $2 / 6$ & $6 / 6$ & $\mathrm{P}=0.0176$ \\
\hline p75 ${ }^{\mathrm{NTR}+}$ CAL-27 cells & $2 / 6$ & $5 / 6$ & $5 / 6$ & $6 / 6$ & \\
\hline Non-sorted CAL-27 cells & $0 / 6$ & $1 / 6$ & $2 / 6$ & $5 / 6$ & $\mathrm{P}=0.0084$ \\
\hline
\end{tabular}

$\mathrm{p} 75^{\mathrm{NTR}}, \mathrm{p} 75$ neurotrophin receptor.
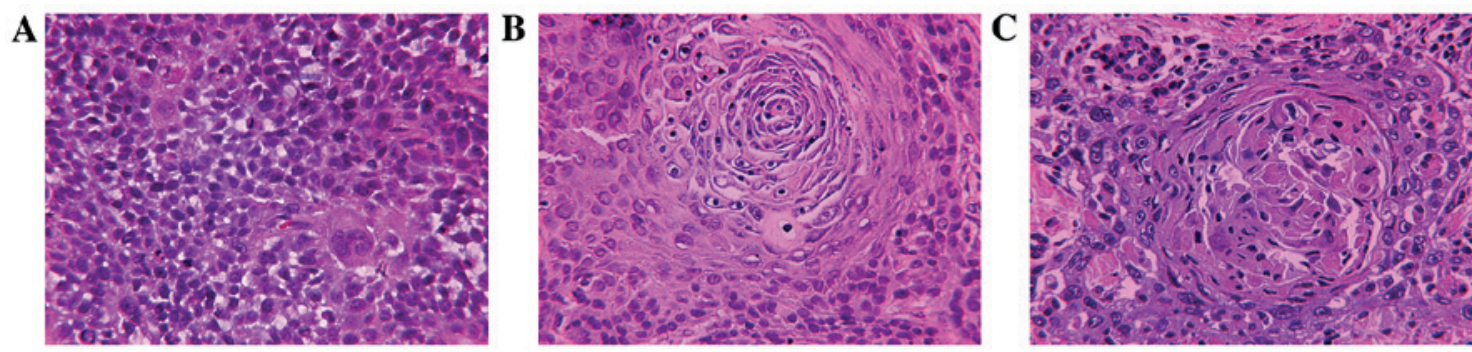

Figure 11. Tumor formation following inoculation with p75 ${ }^{\mathrm{NTR}+}$ TSCC cells (hematoxylin and eosin staining). (A) Tca-8113 and (B) CAL-27 cells. (C) Moderately differentiated human TSCC, used as a positive control. Squamous cell carcinomas with no intercellular bridges and undetectable mitosis were detected. Tumors originating from Tca-8113 cells exhibited larger necrotic areas compared with those derived from CAL-27 cells. Inoculation with both cell lines resulted in the generation of abundant cancer cell nests, which resemble normal human, moderately differentiated TSCC. p75 $5^{\mathrm{NTR}}$, p75 neurotrophin receptor; TSCC, tongue squamous cell carcinoma. A-F, $\mathrm{x} 400$.

indicated that $\mathrm{p} 75^{\mathrm{NTR}}$ may be considered a useful surface marker of TSCC stem cells.

Previous studies have reported on the existence of CSCs in brain tumors $(4,6)$, liver $(31,32)$, lung $(33)$, breast $(34)$, colorectal (35) and pancreatic carcinoma (36), and thyroid tumors (37). Bao et al (38) reported that cluster of differentiation (CD) $133^{+}$CSCs contributed to glioma radioresistance via preferential activation of the DNA damage checkpoint response and increased DNA repair capacity. In addition, the proportion of $\mathrm{CD}_{133^{+}}$cells in these tumors was 2-3\%. Liu et al (39) reported that $\mathrm{CD} 133^{+} \mathrm{CSCs}$, which accounted for $10.2 \%$ of brain glioblastoma cells, exhibited chemoresistance due to their increased expression of ATP-binding cassette sub-family G member 2 and O-6-methylguanine-DNA methyltransferase.

The results of the present study are consistent with those of previous reports, which demonstrated that the expression of p $75^{\mathrm{NTR}}$ is associated with the occurrence and development of numerous types of cancer, including stomach cancer (40), retinal neuroblastoma (41), prostatic carcinoma (42), pancreatic cancer (43) and melanoma (44). The present results suggested that the CSC theory is valid; and a small population of CSCs stimulate tumor recurrence and metastases.

Self-renewal is a hallmark of CSCs, since they are able to form new, identical stem cells that can proliferate, expand and differentiate. Colony-forming ability reflects self-renewal capacity, and previous studies regard colony-forming cells as CSCs $(34,45)$. In the present study, a colony formation assay confirmed that $\mathrm{p} 75^{\mathrm{NTR}+}$ cells exhibited a better colony-forming ability compared with non-sorted cells, and these data agree with the fact that CSCs are capable of self-renewal. In addition, flow cytometry confirmed that the proportion of $\mathrm{p} 75^{\mathrm{NTR}+}$ cells was significantly decreased after 4 weeks of colonization in vitro. Therefore, $\mathrm{p} 75^{\mathrm{NTR}+}$ cells may generate $\mathrm{p} 75^{\mathrm{NTR}+}$ and p $75^{\text {NTR- }}$ progenies, thus suggesting they possess multidirectional differentiation ability.

The results of an MTT assay revealed that the viability of $\mathrm{p} 75^{\mathrm{NTR}+}$ cells was significantly higher compared with non-sorted cells. Invasion and metastasis are important biological characteristics of malignant tumors, which are associated with patient mortality and chemoresistance. According to the results of a scratch assay, $\mathrm{p} 75^{\mathrm{NTR}+}$ cells possess migratory ability. Kiyosue et al (12) reported a significant association between the magnitude of $\mathrm{p} 75^{\mathrm{NTR}}$ positivity and the mode of tumor invasion. Furthermore, Soland et al (46) reported that the average risk of local recurrence was increased by $\sim 17$-fold in OSCC when $\mathrm{p} 75^{\mathrm{NTR}}$ expression was positive, and marked tumor cell dissociation was detected at the invasive front. Therefore, $\mathrm{p} 75^{\mathrm{NTR}+}$ may be involved in the invasive pattern of cancer cells.

In the present study nude mice were inoculated with various numbers of $\mathrm{p} 75^{\mathrm{NTR}+}$ cells isolated from Tca- 8113 and CAL-27 TSCC cell lines, or non-sorted cells, in order to determine whether $\mathrm{p} 75^{\mathrm{NTR}+}$ cells exhibit greater tumorigenicity compared with non-sorted cells. The results indicated that that $\mathrm{p} 75^{\mathrm{NTR}+}$ cells possess stronger tumorigenicity. H\&E staining revealed that the inoculated mice possessed squamous cell carcinoma with no intercellular bridges and undetectable mitosis. In addition, Tca-8113 cell tumors manifested larger necrotic areas compared with those derived from CAL-27 cells. Both tumor types possessed abundant cancer cell nests, 
which resembled normal human, moderately differentiated TSCC. Therefore, the present study suggested that $\mathrm{p} 75^{\mathrm{NTR}+}$ cells may be useful for the surface marker identification of TSCC stem cells.

In conclusion, p75 neurotrophin receptor (p75 ${ }^{\mathrm{NTR}}$ ) expression was detected in TSCC cell lines and found that $\mathrm{p} 75^{\mathrm{NTR}+}$ cells isolated from TSCC cell lines possess the characteristics of cancer stem cells. These findings suggest that $\mathrm{p} 75^{\mathrm{NTR}}$ may be considered a useful surface marker for the identification of TSCC stem cells, providing a potential target for novel therapies.

\section{Acknowledgements}

The present study was supported by the Shandong Province Science and Technique Foundation, China (grant no. ZR2012HM055) to Professor Fenghe Zhang.

\section{References}

1. Warnakulasuriya S: Global epidemiology of oral and oropharyngeal cancer. Oral Oncol 45: 309-316, 2009.

2. Hamburger AW and Salmon SE: Primary bioassay of human tumor stem cells. Science 197: 461-463, 1977.

3. Reya T, Morrison SJ, Clarke MF and Weissman IL: Stem cells, cancer, and cancer stem cells. Nature 414: 105-111, 2001.

4. Singh SK, Hawkins C, Clarke ID, Squire JA, Bayani J, Hide T, Henkelman RM, Cusimano MD and Dirks PB: Identification of human brain tumour initiating cells. Nature 432: 396-401, 2004.

5. Costea DE, Tsinkalovsky O, Vintermyr OK, Johannessen AC and Mackenzie IC: Cancer stem cells - new and potentially important targets for the therapy of oral squamous cell carcinoma. Oral Dis 12: 443-454, 2006.

6. Singh SK, Clarke ID, Terasaki M, Bonn VE, Hawkins C, Squire J and Dirks PB: Identification of a cancer stem cell in human brain tumors. Cancer Res 63: 5821-5828, 2003.

7. Seigel GM, Campbell LM, Narayan M and Gonzalez-Fernandez F: Cancer stem cell characteristics in retinoblastoma. Mol Vis 11: 729-737, 2005

8. Chumsri S, Phatak P, Edelman MJ, Khakpour N, Hamburger AW and Burger AM: Cancer stem cells and individualized therapy. Cancer Genomics Proteomics 4: 165-74, 2007.

9. Locke M, Heywood M, Fawell S and Mackenzie IC: Retention of intrinsic stem cell hierarchies in carcinoma-derived cell lines. Cancer Res 65: 8944-8950, 2005.

10. Tudor D, Locke M, Owen-Jones E and Mackenzie IC: Intrinsic patterns of behavior of epithelial stem cells. J Investig Dermatol Symp Proc 9: 208-214, 2004

11. Dean M, Fojo T and Bates S: Tumour stem cells and drug resistance. Nat Rev Cancer 5: 275-284, 2005.

12. Kiyosue T, Kawano S, Matsubara R, Goto Y, Hirano M, Jinno T, Toyoshima T, Kitamura R, Oobu K and Nakamura S Immunohistochemical location of the p75 neurotrophin receptor (p75NTR) in oral leukoplakia and oral squamous cell carcinoma. Int J Clin Oncol 18: 154-163, 2013.

13. Rabizadeh S and Bredesen DE: Ten years on: Mediation of cell death by the common neurotrophin receptor p75(NTR). Cytokine Growth Factor Rev 14: 225-239, 2003.

14. Liepinsh E, Ilag LL, Otting G and Ibáñez CF: NMR structure of the death domain of the p75 neurotrophin receptor. EMBO J 16: 4999-5005, 1997.

15. Rodríguez-Tébar A, Dechant G, Götz R and Barde YA: Binding of neurotrophin-3 to its neuronal receptors and interactions with nerve growth factor and brain-derived neurotrophic factor. EMBO J 11: 917-922, 1992.

16. Wang X, Bauer JH, Li Y, Shao ZH, Zetoune FS, Cattaneo E and Vincenz C: Characterization of a p75(NTR) apoptotic signaling pathway using a novel cellular model. J Biol Chem 276: 33812-33820, 2001.

17. Harding TC, Xue L, Bienemann A, Haywood D, Dickens M, Tolkovsky AM and Uney JB: Inhibition of JNK by overexpression of the JNL binding domain of JIP-1 prevents apoptosis in sympathetic neurons. J Biol Chem 276: 4531-4534, 2001.
18. Park DS, Morris EJ, Bremner R, Keramaris E, Padmanabhan J, Rosenbaum M, Shelanski ML, Geller HM and Greene LA: Involvement of retinoblastoma family members and E2F/DP complexes in the death of neurons evoked by DNA damage. J Neurosci 20: 3104-3114, 2000.

19. Salehi AH, Xanthoudakis $\mathrm{S}$ and Barker PA: NRAGE, a p75 neurotrophin receptor-interacting protein, induces caspase activation and cell death through a JNK-dependent mitochondrial pathway. J Biol Chem 277: 48043-48050, 2002.

20. Krygier S and Djakiew D: Neurotrophin receptor p75(NTR) suppresses growth and nerve growth factor-mediated metastasis of human prostate cancer cells. Int J Cancer 98: 1-7, 2002.

21. Khwaja F and Djakiew D: Inhibition of cell-cycle effectors of proliferation in bladder tumor epithelial cells by the p75NTR tumor suppressor. Mol Carcinog 36: 153-160, 2003.

22. Pflug BR, Onoda M, Lynch JH and Djakiew D: Reduced expression of the low affinity nerve growth factor receptor in benign and malignant human prostate tissue and loss of expression in four human metastatic prostate tumor cell lines. Cancer Res 52: 5403-5406, 1992.

23. Okumura T, Shimada Y, Imamura $M$ and Yasumoto $S$ : Neurotrophin receptor p75(NTR) characterizes human esophageal keratinocyte stem cells in vitro. Oncogene 22: 4017-4026, 2003.

24. Campagnolo L, Russo MA, Puglianiello A, Favale A and Siracusa G: Mesenchymal cell precursors of peritubular smooth muscle cells of the mouse testis can be identified by the presence of the p75 neurotrophin receptor. Biol Reprod 64: 464-472, 2001.

25. Yamamoto N, Akamatsu H, Hasegawa S, Yamada T, Nakata S, Ohkuma M, Miyachi E, Marunouchi T and Matsunaga K: Isolation of multipotent stem cells from mouse adipose tissue. J Dermatol Sci 48: 43-52, 2007.

26. Qi H, Li DQ, Shine HD, Chen Z, Yoon KC, Jones DB and Pflugfelder SC: Nerve growth factor and its receptor TrkA serve as potential markers for human corneal epithelial progenitor cells. Exp Eye Res 86: 34-40, 2008.

27. Rota LM, Lazzarino DA, Ziegler AN, LeRoith D and Wood TL: Determining mammosphere-forming potential: Application of the limiting dilution analysis. J Mammary Gland Biol Neoplasia 17: 119-123, 2012.

28. Liang CC, Park AY and Guan JL: In vitro scratch assay: A convenient and inexpensive method for analysis of cell migration in vitro. Nat Protoc 2: 329-333, 2007.

29. Eramo A, Lotti F, Sette G, Pilozzi E, Biffoni M, Di Virgilio A, Conticello C, Ruco L, Peschle C and De Maria R: Identification and expansion of the tumorigenic lung cancer stem cell population. Cell Death Differ 15: 504-514, 2008.

30. Collins AT, Berry PA, Hyde C, Stower MJ and Maitland NJ: Prospective identification of tumorigenic prostate cancer stem cells. Cancer Res 65: 10946-10951, 2005.

31. Ma S, Chan KW, Hu L, Lee TK, Wo JY, Ng IO, Zheng BJ and Guan XY: Identification and characterization of tumorigenic liver cancer stem/progenitor cells. Gastroenterology 132: 2542-2556, 2007.

32. Zen Y, Fujii T, Yoshikawa S, Takamura H, Tani T, Ohta T and Nakanuma Y: Histological and culture studies with respect to ABCG2 expression support the existence of a cancer cell hierarchy in human hepatocellular carcinoma. Am J Pathol 170: $1750-1762,2007$

33. Seo DC, Sung JM, Cho HJ, Yi H, Seo KH, Choi IS, Kim DK, Kim JS, El-Aty AM A and Shin HC: Gene expression profiling of cancer stem cell in human lung adenocarcinoma A549 cells. Mol Cancer 6: 75, 2007.

34. Liu SL, Dontu G, Mantle ID, Patel S, Ahn NS, Jackson KW, Suri $\mathrm{P}$ and Wicha MS: Hedgehog signaling and Bmi-1 regulate self-renewal of normal and malignant human mammary stem cells. Cancer Res 66: 6063-6071, 2006.

35. Ricci-Vitiani L, Lombardi DG, Pilozzi E, Biffoni M, Todaro M, Peschle $\mathrm{C}$ and De Maria R: Identification and expansion of human colon-cancer-initiating cells. Nature 445: 111-115, 2007.

36. Li C, Heidt DG, Dalerba P, Burant CF, Zhang L, Adsay V, Wicha M, Clarke MF and Simeone DM: Identification of pancreatic cancer stem cells. Cancer Res 67: 1030-1037, 2007.

37. Mitsutake N, Iwao A, Nagai K, Namba H, Ohtsuru A, Saenko V and Yamashita S: Characterization of side population in thyroid cancer cell lines: Cancer stem-like cells are enriched partly but not exclusively. Endocrinology 148: 1797-1803, 2007.

38. Bao S, Wu Q, McLendon RE, Hao Y, Shi Q, Hjelmeland AB, Dewhirst MW, Bigner DD and Rich JN: Glioma stem cells promote radioresistance by preferential activation of the DNA damage response. Nature 444: 756-760, 2006. 
39. Liu G, Yuan X, Zeng Z, Tunici P, Ng H, Abdulkadir IR, Lu L, Irvin D, Black KL and Yu JS: Analysis of gene expression and chemoresistance of CD133+ cancer stem cells in glioblastoma. Mol Cancer 5: 67, 2006.

40. Jin H, Pan Y, Zhao L, Zhai H, Li X, Sun L, He L, Chen Y, Hong L, Du Y and Fan D: p75 neurotrophin receptor suppresses the proliferation of human gastric cancer cells. Neoplasia 9: 471-478, 2007.

41. Dimaras H and Gallie BL: The p75 (NTR) neurotrophin receptor is a tumor suppressor in human and murine retinoblastoma development. Int J Cancer 122: 2023-2029, 2008.

42. Khwaja F, Tabassum A, Allen J and Djakiew D: The p75(NTR) tumor suppressor induces cell cycle arrest facilitating caspase mediated apoptosis in prostate tumor cells. Biochem Biophys Res Commun 341: 1184-1192, 2006.
43. Dang CX, Zhang Y, Ma QY and Shimahara Y: Expression of nerve growth factor receptors is correlated with progression and prognosis of human pancreatic cancer. J Gastroen Hepatol 21: 850-858, 2006.

44. Marchetti D, Aucoin R, Blust J, Murry B and Greiter-Wilke A: p75 neurotrophin receptor functions as a survival receptor in brain-metastatic melanoma cells. J Cell Biochem 91: 206-215, 2004.

45. Diamandis P, Wildenhain J, Clarke ID, Sacher AG, Graham J, Bellows DS, Ling EK, Ward RJ, Jamieson LG, Tyers $M$ and Dirks PB: Chemical genetics reveals a complex functional ground state of neural stem cells. Nat Chem Biol 3: 268-273, 2007.

46. Soland TM, Brusevold IJ, Koppang HS, Schenck K and Bryne M: Nerve growth factor receptor (p75 NTR) and pattern of invasion predict poor prognosis in oral squamous cell carcinoma. Histopathology 53: 62-72, 2008. 